\title{
Cordula Bandt
}

\section{Psalms as Part of the Worship in Early Christian Exegesis}

In:

Origeniana duodecima : Origen's legacy in the Holy Land - a tale of three cities: Jerusalem, Caesarea and Bethlehem : proceedings oft he 12th International Origen Congress, Jerusalem, 25-29 June, 2017 / edited by Brouria Bitton-Ashkelony, Oded Irshai, Aryeh Kofsky, Hillel Newman, Lorenzo Perrone. - ISBN: 978-90-429-3947-9

Leuven: Peeters, 2019. S. 477-488

(Bibliotheca ephemeridum theologicarum Iovaniensium ; 302) 


\section{ORIGENIANA DUODECIMA}

\section{ORIGEN'S LEGACY IN THE HOLY LAND - A TALE OF THREE CITIES: \\ JERUSALEM, CAESAREA AND BETHLEHEM}

Proceedings of the 12th International Origen Congress, Jerusalem, 25-29 June, 2017

BROURIA BITTON-ASHKELONY - ODED IRSHAI ARYEH KOFSKY - HILLEL NEWMAN - LORENZO PERRONE 


\title{
TABLE OF CONTENTS
}

ACKNOWLEDGMENTS $\ldots \ldots \ldots \ldots \ldots \ldots \ldots \ldots \ldots \ldots$ XIII

\section{PROLEGOMENON}

Lorenzo PERrone (Bologna)

Origen and His Legacy in the "Holy Land": Fortune and Misfortune of a Literary and Theological Heritage .......... 3

\author{
I. JERUSALEM AND THE HOLY LAND: \\ HISTORICAL AND MYSTICAL GEOGRAPHY
}

Agnès Aliau-Milhaud (Paris)

Bethabara and Gergesa (Origen, Commentary on John VI,204211): Geographical Digression or Exegesis? .......... 31

Marie-Odile Boulnois (Paris)

Mambré: Du chêne de la vision au lieu de pèlerinage.......

Harald BuCHINGER (Regensburg)

Pascha in Third-Century Palestine: Origen's Newly Identified

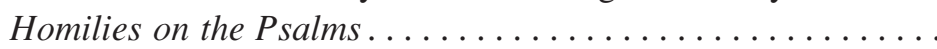

Antonio CACCIARI (Bologna)

The Fall of Jerusalem in Origen's Newly Discovered Homilies on the Psalms............................

Lavinia CERIONI (Roma)

"Mother of Souls": The Holy City of Jerusalem in Origen's Commentary and Homilies on the Song of Songs. . . . . . . . . 109

Giovanni Hermanin de ReICHENFEld (Roma)

From Capernaum to Jerusalem: Noetic History and Historical Occurrences in Origen's Sacred Geography of the Holy Land .

Tommaso INTERI (Torino)

"A Place to Worship the Lord Our God": Origen's Exegesis of the Holy Land in His Homilies on the Prophets.......... 
Nikolai LiPATOV-CHICHERIN (Nottingham)

Early Christian Tradition about Adam's Burial on Golgotha and

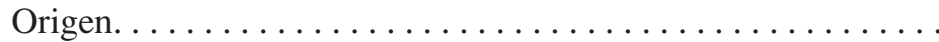

Valentina MARChETTO (Bologna)

"Jerusalem ... Is the Divine Soul" (FrLam VIII): The Holy Land in Origen's Early Works ...................

Christoph MARKSCHIES (Berlin)

Local Knowledge vs. Religious Imaging: Origen and the Holy Land . . . . . . . . . . . . . . . . . . . . . . . . . . 205

Emanuela PRINZIVALLi (Roma)

The City of God and the Cities of Men according to Origen ..

Franz Xaver Risch (Berlin)

Die Stufen des Tempels: Zur Auslegung der Gradualpsalmen bei Origenes . . . . . . . . . . . . . . . . . . . . . . . . . . . . . . . 243

\section{THE SCHOOL OF CAESAREA AND EUSEBIUS}

Pier Franco BeAtrice (Padova)

Porphyry at Origen's School at Caesarea . . . . . . . . . . 267

Francesco CELIA (Jerusalem)

Studying the Scriptures at the School of Caesarea: The Testimony of Gregory of Neocaesarea's Oratio Panegyrica . . . . . . .

Mark DelCogliano (St. Paul, MN)

Eusebius of Caesarea's Defense of Origen in Contra Marcellum I,4,1-27 . . . . . . . . . . . . . . . . . . . . . . . . . .

Pedro Daniel Fernández (San Juan)

Alexandrie et Césarée: La continuité de l'itinéraire pédagogique d'Origène.

Marc HiRSHMAN (Jerusalem)

Origen, Copyists, and Books of Aggada........... 317

Aaron P. Johnson (Cleveland, TN)

Cities Divine and Demonic in Eusebius of Caesarea . . . . . . . 325

Adele Monaci Castagno (Torino)

Eusèbe de Césarée, Jérusalem et la Palestine: Une question controversée. 
Sébastien MORLET (Paris)

$\Sigma u \mu \varphi \omega v i \alpha$ : Symphonic Exegesis from Origen to Eusebius of

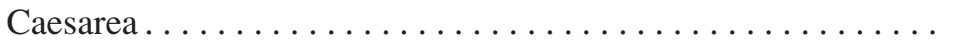

Joseph PATRICH (Jerusalem)

Caesarea Maritima in the Time of Origen . . . . . . . . . . . 375

III. ORIGEN'S LATIN LEGACY: RUFINUS AND JEROME

Andrew CAIN (Boulder, CO)

Origen, Jerome's Pauline Prefaces, and the Architecture of Exegetical Authority ....................... 413

Maurizio GIROLAMI (Pordenone)

Bible and/or Tradition in the Works of Origen, Rufinus, and Jerome

Justin J. LEE (Durham)

"Seek and Ye Shall Find": Rufinus and the Search for Origen's Trinitarian Orthodoxy .....................

Katarina PÅLSSON (Lund)

Likeness to the Angels: Origen, Jerome, and the Question of the Resurrection Body

\section{TRADITION, INNOVATION, AND HERITAGE: ORIGEN'S EXEGESIS AND THEOLOGY}

Cordula BANDT (Berlin)

Psalms as Part of the Worship in Early Christian Exegesis....

Carl Johan Berglund (Uppsala)

Discerning Quotations from Heracleon in Origen's Commentary on the Gospel of John . . . . . . . . . . . . . . . . .

Andrew BLASKI (Champaign, IL)

Jews, Christians, and the Conditions of Christological Interpretation in Origen's Work . . . . . . . . . . . . . . . . 505

Gerald Bostock (Perth)

Origen's Unique Doctrine of the Trinity: Its Jewish and Egyptian

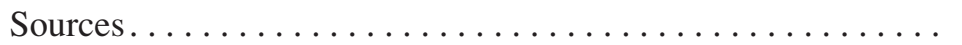


Stephen C. CARLSON (Fitzroy)

Origen's Use of Papias ........................ 535

Elizabeth Ann Dively Lauro (Los Angeles, CA)

History and Context of Origen's Relation of the Two Seraphim to the Son and Holy Spirit. . . . . . . . . . . . . . . . . . .

Samuel FERNÁNDEZ (Santiago)

"That Man Who Appeared in Judaea" (Prin II,6,2): The Soteriological Function of the Humanity of the Son of God according to Origen's De principiis.......................... 563

Alfons FüRST (Münster)

Matter and Body in Origen's Christian Platonism . . . . . . . . . 573

Anders-Christian JACOBSEN (Aarhus)

Origen on Body and Soul ........................ 589

Samuel Johnson (Notre Dame, IN)

The Sacrifice of the Law in Origen's Homilies on Leviticus. . 603

Jussi Pentti Junni (Helsinki)

Being and Becoming in Celsus and Origen ............. 617

Lenka Karfíková (Prague)

Is Romans 9,11 Proof for or against the Pre-Existence of the Soul? Origen and Augustine in Comparison ............. 627

Vito Limone (Milano)

Ousia in Origen: The Use of the Term in Light of the Homilies on the Psalms.....................................................

Francesca MinOnNE (Milano)

Origen and the Grammatical Process of Interpretation: 'Y $\mathrm{\varepsilon} \varepsilon \rho \beta \alpha \tau \dot{\alpha}$ as Solutions to Solecisms . . . . . . . . . . . . . . . . . .

Domenico PAZZINI (Verucchio)

Le lieu de Jésus et la voie négative de l'épinoia dans le Commentaire sur Saint Jean d'Origène ................. 671

Gianluca PISCINI (Tours)

Trois versions de Phinees: Nb 25,7-8 dans la tradition alexandrine (Philon, Origène, Cyrille) ........................

Anna ZhYrkova (Kraków)

The Philosophical Premises of Origen's Teachings on the Subject of Christ as an Ontological Unity ............... 
Vladimir A. BARANOV (Novosibirsk)

The First Responses to Iconoclasm in Byzantium and Origen's Tradition: The Cases of Constantinople and Palestine. . . . . . 711

Maria FAllicA (Roma)

Origen and the Glorified Body: Bullinger, Sozzini and Calvin

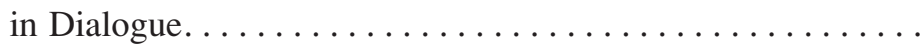

Cornelis HoOgerwerf (Leiden)

Origen, "Destroyer of the Holy Scriptures"? Origen and Theodore of Mopsuestia on Ephesians 5,31-32. .

Raffaele TONDINI (Padova)

Photius as Origen's Reader (and Editor).

Robin Darling Young (Washington, DC)

Evagrius and the Christian Interpretation of the Psalms: Proposals for Further Investigation $\ldots \ldots \ldots \ldots \ldots \ldots \ldots \ldots$

John ZALESKI (Cambridge, MA)

The Nous Is the Head of the Soul: Remaking Origen's and Evagrius's Anthropology for the Church of the East . . . . . . . 789

Elisa Zocchi (Münster)

"Where the Human Senses Become Spiritual, Faith Becomes Sensory": Corporeality and Spiritual Senses in Balthasar's Reading of Origen . . . . . . . . . . . . . . . . . 805

\section{INDICES}

ABbreVIATIONES ......................... 823

SACRA SCRIPTURA . . . . . . . . . . . . . . . . . . . . 825

ORIGENIS OPERA..................... 835

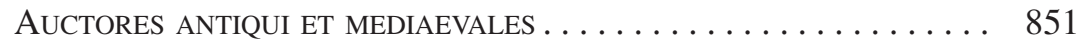

Auctores MOdERni. . . . . . . . . . . . . . . . . . 877 


\section{PSALMS AS PART OF THE WORSHIP IN EARLY CHRISTIAN EXEGESIS}

The following contribution is connected to the work on the prologue material in the catenae on Psalms taken from the works of Origen and Eusebius. Within the framework of the Berlin editorial project, "Die alexandrinische und antiochenische Bibelexegese in der Spätantike", new critical editions of these prologue texts have been published in a joint volume ${ }^{1}$. Meant as introductions for readers of the psalter, they present a wide variety of themes, ranging from technical explanations to historical and theological comments. As many psalms are associated with the Temple in Jerusalem and originally formed a part of its worship and liturgy, the following will examine early Christian exegesis on Psalms, its awareness of these links, and its assessment of the ancient worship.

\section{Christian Claiming of the Psalms}

In the gospels, Jesus himself exhibits a rather negative approach towards the contemporary Temple, specifically its overseers ${ }^{2}$. Early Christian authors often display the same perception of the earthly temple in earthly Jerusalem. It had been the place of sacrifice according to the law, but these $\sigma \omega \mu \alpha \tau 1 \kappa \alpha ̀$ $\vartheta v \sigma i \alpha^{3}$ had been abolished by Christ. Instead, hopes were placed on the heavenly New Jerusalem and its temple. History was invoked to support this perception, since the Second Temple had been demolished not long after Jesus' death. But still, since "the law has a shadow of the good things to come" 4 , to quote one of Origen's as well as one of Eusebius' favorite verses from Paul, and probably also because of the presence of the remaining Temple ruins, as Franz Xaver Risch shows in his contribution ${ }^{5}$, Origen and others also took the Temple's architecture and the actions of the priests into account.

1. C. Bandt - F.X. Risch - B. Villani, Die Prologtexte zu den Psalmen von Origenes und Eusebius (TU, 183), Berlin, De Gruyter, 2018.

2. See Mt 21,12-16 parr.

3. See e.g. Eusebius, Comm. in Ps. 68 (PG 23, 760C).

4. Heb 10,1 .

5. See F.X. Risch, Die Stufen des Tempels: Zur Auslegung der Gradualpsalmen bei Origenes, in the present volume, 243-263. 
The Psalms, on the other hand, played a vital role in Christian personal piety as well as in common gatherings. Therefore, the exegesis had to provide their fellow Christians with appropriate, uplifting interpretations. Thus, Origen often concentrated on the ethical perspective and taught his audience how to conduct a proper Christian life according to the psalm verses $^{6}$. Eusebius, in turn, takes every opportunity to allude to Christian salvation history ${ }^{7}$. In fact, the interpretation of psalm verses as prophecies about Christ is widespread, and we find it already in Peter's address to the crowd at Pentecost ${ }^{8}$. Ultimately, such an interpretation of the Psalms leads to their virtual detachment from Judaism. Sometimes, they are even set in sharp contrast to it, as in the almost bizarre reasoning from Eusebius in his rather popular prologue text to the psalter:

On the fact that the Book of Psalms contains a new teaching after Moses' Law and is a second educational book, after the writing of Moses. After Moses' and Joshua's death and after the Judges, David was born and was found worthy to act in a way as the father of the savior, and he first introduced to the Hebrews the chanting of psalms as a new practice. By means of it, he abolishes Moses' Law regarding sacrifices and introduces as a new kind of service the one of praising and exultation. And, the other things which exceed the Law of Moses, he teaches in his whole work ${ }^{9}$.

In this succinct statement, the psalter becomes kind of an intertestamental piece. In fact, it affects the Mosaic Law insofar as legal sacrifices are abolished and replaced by the chanting of psalms, $\psi \alpha \lambda \mu \omega \delta i \alpha$. David,

6. This exegetical scope is omnipresent throughout the newly found homilies. See $e . g$. Origenes, H67Ps II, 2 (GCS NF 19, 202,9-204,4 PERRONE). 3 (206,20-207,3). 4 (209,2211,2). $5(212,8-215,2)$ etc.

7. To get an idea of the prominence of this theme within Eusebius' enormous Commentary on the Psalms, already one glance at the Periochae is sufficient. In the Periochae Eusebius summarizes in few words his interpretation of every single psalm. Far more than half of the psalms are categorized by Eusebius in their entirety as prophesies about Christ's earthly life, his passion and resurrection, the repudiation of the Jews, and, most prominent, the call of the pagans. The Periochae are very popular in the Psalm catenae, they have been published by Montfaucon (see PG 23, 68A-72C), a new edition is incorporated in the above mentioned volume on the prologue material by Origen and Eusebius (see n. 1).

8. See Act 2,25: "For David speaketh concerning him: 'I foresaw the Lord always before my face, for he is on my right hand, that I should not be moved' (Ps 15,8 = Ps 16,8 M)".

9. Eusebius, Didascalia (cf. PG 23, 76A, critical edition included in the volume men-

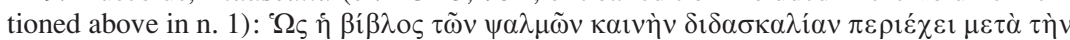

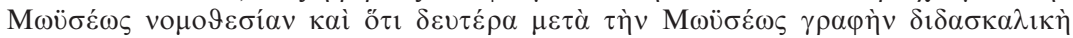

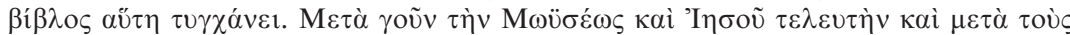

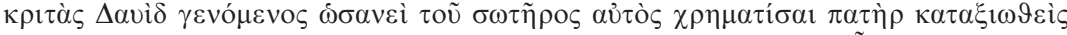

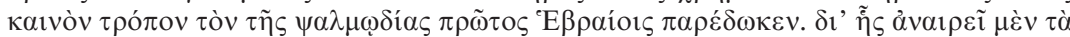

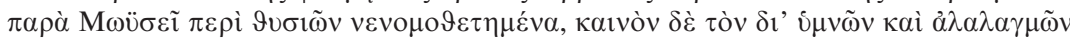

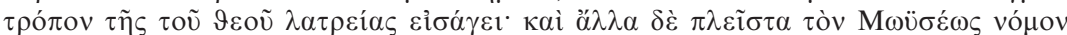

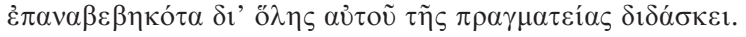


the inventor of $\psi \alpha \lambda \mu \omega \delta$ í $\alpha$, is called the "father of the savior", which, of course, coincides which Mt 1,1. However, this title can be interpreted in a twofold manner: on the one hand, according to Eusebius' understanding that almost all psalms are speaking about Christ and his church, and likewise for him, the psalter, regarding its content, is a forerunner of the gospels. On the other hand, regarding its function, $\psi \alpha \lambda \mu \omega \delta i \alpha$ is portrayed as a substitute for the sacrifices and therefore a forerunner of the Eucharist.

Still, it must be asked, which meaning of $\psi \alpha \lambda \mu \omega \delta$ í $\alpha$ did Eusebius have in mind when he stated that David introduced it to the Hebrews? Being a historian and well versed in biblical history, he was certainly aware of the report of the return of the Ark of Covenant to Jerusalem in 2 Sam 6, wherein David danced and sang before the Ark (cf. 2 Sam 6,5.14.21). This was extraordinary behavior for a king of Judah, as the dismayed reaction to this performance by David's first wife, Michal, shows (cf. 2 Sam 6,20). However, according to this report, during the ceremony King David not only performed music but also offered a great number of sacrifices (cf. 2 Sam 6,13.17). Eusebius must have known that the sacrifice of animals in the sanctuary was sanctioned during David's lifetime and until the Second Temple was destroyed.

Therefore, it seems unlikely that Eusebius thought that the Jewish people as a whole might have benefitted from David's innovation of $\psi \alpha \lambda$ $\mu \omega \delta i ́ \alpha$ as a substitute for these sacrifices. A passage from his Commentary on Psalm 53 sheds light on the matter. Here we learn more about the circumstances of this innovation, and that it took place in the dramatic context of David's flight from Saul, when he was cut off from the sanctuary and thus could not offer a sacrifice ${ }^{10}$ :

... he calls us for understanding of the content in the words: "Towards the end, in hymns, out of understanding, by David" (Ps 53,1) [...], because when he was fleeing and was hunted in the desert, he armed himself instead of an amulet with the instrument of the harp and the hymns which were send up to God by its means, and he used spiritual songs and psalms instead of sacrifices, and he implemented the spiritual liturgy instead of the flavoursome incense $\mathrm{e}^{11}$.

10. This argument is to a certain degree anachronistic, because as 1 Sam 14,35 shows, it would have been possible to sacrifice spontaneously away from the sanctuary in the time of Saul and David.

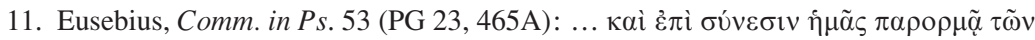

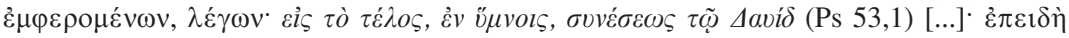

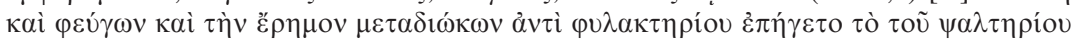

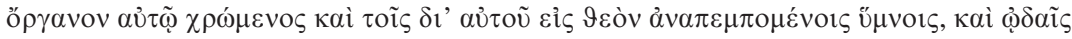

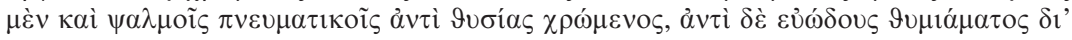

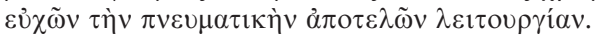


This means that Eusebius dates the introduction of $\psi \alpha \lambda \mu \omega \delta$ í $\alpha$ by David back to the times when he was not yet a king, and he understands it in David's case as an act of personal piety, not as a collective service. Of course, here Eusebius is commenting on just one single psalm verse, but the prologue text quoted before strongly suggests that he generally uncouples the performance of psalms and the service in the sanctuary. We will return to this observation later.

\section{The Appointment of Musicians Before THE ARK}

When David made Jerusalem the capital of his kingdom and brought the Ark from Kirjat-Jearim there, he was not the only musician who took part in the triumphal procession. As we learn from corresponding reports in the First Book of Chronicles, the king appointed a number of liturgical musicians from the tribe of Levi. The different lists of these musicians are not identical ${ }^{12}$, but three principal musicians (simply called $\psi \alpha \lambda \tau \omega \delta$ oí, cf. $1 \mathrm{Chr}$ 15,16) were chosen. The names were spelled either Aiman, Asaf and Aitham (cf. 1 Chr 15,17) or Asaf, Aiman and Idithum (cf. 1 Chr 25,1). These performers also led the musical service in the newly established sanctuary in Jerusalem. Together with their offspring, they formed a total number of 288 musicians (cf. 1 Chr 25,7); 24 groups of twelve men each (cf. 1 Chr 25,8-31). These numbers are not further explained, but it is clear that the number twelve constitutes their basis. The number twelve, in turn, is a formative principle in the structure of the sanctuary, as it represents the twelve tribes of Israel ${ }^{13}$.

Significantly, while David is the most prominent author in the Book of Psalms, all four names of the chief musicians also appear in the headings of several psalms. This is probably due to the fact that, in his Homily on Psalms, Hippolytus of Rome took the reports from Chronicles as a stimulus to write his own astonishingly embellished version, although he diverts notably from the biblical account ${ }^{14}$. After a short historical summary of the circumstances leading to the return of the Ark of Covenant to Jerusalem, Hippolytus speaks of the assignment for the chief musicians (ö $\rho \chi o v \tau \varepsilon \varsigma$ $\omega \delta \tilde{\omega} v)$. By combining both above-mentioned accounts of musicians from Chronicles, he enlarges the number from three to four, Asaf, Aiman,

12. The musicians are listed in $1 \mathrm{Chr} 5,16-32 ; 15,16-24$ and $16,4-6.37-42 ; 25,1-31$.

13. Already during the Exodus for the sacrifice before the Book of the Covenant is read, twelve pillars are erected by Moses according to the number of twelve tribes of Israel (cf. Ex 24,4). See also the description of the twelve stones in the Ephod of the High priest (Ex 39,10-14 = Ex 38,17-21LXx) and the twelve loafs of bread on the altar table (Lev 24,5f.).

14. For the following see Hippolytus, In Psalmos 2f. (167,6-169,11, ed. P. NAUTIN). 
Aitham and Idithum. This expansion allows him to split the total number of 288 musicians into a completely different symbolic notion than his biblical model, presenting a truly universal concept. Each of the four chief musicians, he states, was leading a group, or perhaps a choir, of 72 men. He interprets the number 72 as a representation of the whole mankind, because when humanity had one language, before the Tower of Babylon was built, there were a total of (more or less) ${ }^{15} 72 \stackrel{\varepsilon}{\varepsilon} \vartheta \vee \eta$ as descendants of Noah's sons Ham, Sem and Jafet. By the nomination of 288 musicians in the sanctuary David is, to Hippolytus' understanding, not referring to the twelve tribes of Israel, but predicting that the whole of mankind, $\pi \tilde{\alpha} \sigma \alpha$ $\gamma \lambda \tilde{\omega} \sigma \sigma \alpha$ (Rom 14,11; Phil 2,11 cf. Isa 45,23), will praise God at the end of the days.

In the next paragraph, Hippolytus provides a detailed description of the worship before the ark, which I quote at length:

These men (sc. the four chief musicians) stood before the sanctuary and praised God, one with cymbals, another with the harp, another with the lyre, another with the horn, whereby he elevated the heightened horn of the Lord. David as the chief of the chief musicians was standing in the middle of them with the harp in his hand, and they were accompanied by their groups. Everyone was praising God, inspired by the Holy Spirit. Whenever now the Spirit jumped onto the blessed Asaf, all others became quiet and kept a peaceful moment while they were instructed by the Spirit. Then, they answered the singer for the praise of God "Hallelujah", which means when translated from the Hebrew into the Greek tongue: "Let us praise the living God". Now, they all became recipients; but whenever the Spirit jumped onto the first one and captured him, the others stopped. Whenever the Spirit jumped on the next one, they again kept silent ${ }^{16}$.

In fact, Hippolytus depicts here not only his vision of how worship might have been performed in those days, but states his idea of the psalms' composition method itself ${ }^{17}$. This is especially remarkable insofar as none

15. Cf. Gen 10.

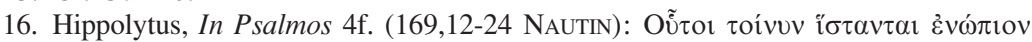

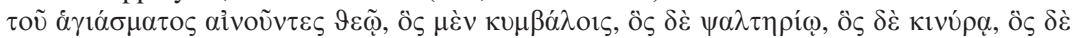

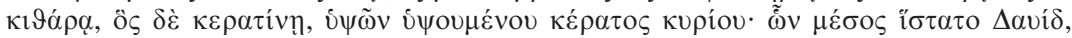

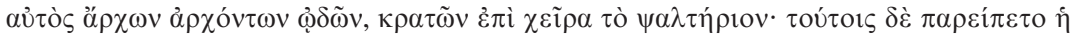

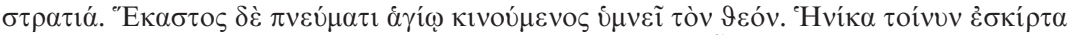

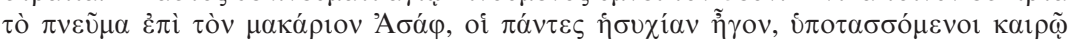

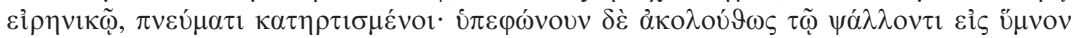

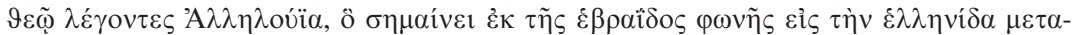

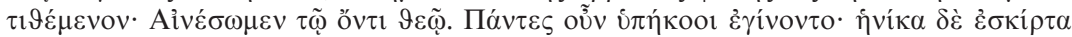

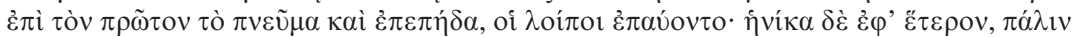

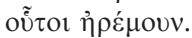

17. This also becomes clear in the following passages of Hippolytus' homily, where he speaks about the different authors of the psalms, cf. Hippolytus, In Psalmos 6f. (171,1-32 NAUTIN). 
of the biblical reports of the appointment of the chief musicians by David links them with the composition of psalms ${ }^{18}$. This connection is originally established by Hippolytus from the psalms' headings, which we will turn to now.

\section{The HeAdings of The Psalms}

For the most part, the psalm headings ascribe authorship to David, but some headings attribute their psalms to other biblical figures. Of course, these assignments are either fictitious or later additions as far as the Hebrew Bible is concerned, and they are even less trustworthy in the LXX where only very few psalms lack a credit of authorship.

It was probably Origen who was the first to set up a dual list showing which psalms were attributed to which author in the Hebrew and Greek versions of the psalter ${ }^{19}$. This list starts with the Hebrew Bible. Here, we encounter names which we already learned from Hippolytus: David, Asaf, Aitham. However, neither Aiman nor Idithum are included in the account, which is due to the fact that their names occur in psalms with attributions to more than one author, and Origen(?) counted every psalm only once. Instead, we learn of the sons of Kore ${ }^{20}$, of Solomon and of Moses. Regarding the Greek version, the names Haggai and Zechariah are also listed.

Based solely on the Hebrew psalter, probably from Origen's Hexapla, Eusebius compiled a table in which the numbers of the psalms are assigned to the related author ${ }^{21}$ and include a brief summary, which adds up the number of psalms attributed to each author ${ }^{22}$.

18. But David's Psalm of Thanksgiving at the end of the report in 1 Chr 16,7-36 is a combination of verses from Pss 104.95.28 and 105 (LXX = Pss 105.96.29 and $106 \mathrm{M}$ ).

19. Origenes(?), De divisione psalmorum. The attribution to Origen is likely, but not completely sure. A critical edition of this text accompanied by a discussion of its authenticity is included in the above-mentioned volume on the prologue material by Origen and Eusebius (see n. 1), for an edition based on two manuscripts see J.-B. PITRA, Analecta sacra Spicilegio Solesmensi parata, II, Paris, Jouby et Roger, 1884, pp. 413-418.

20. It is not entirely clear, who is behind this phrase. Hippolytus explains, that psalms with this heading are joint works of Asaph and Aiman (see Hippolytus, In Psalmos 6 [171,8 NAUTIN]). Korach/Kore indeed appears in the genealogy of Aiman (1 Chr 6,22).

21. Eusebius, Canones Psalmorum. A new edition of this piece by Martin Wallraff is included in the already mentioned volume on the prologue material from Origen and Eusebius (see n. 1). See also G. Mercati, Osservazioni a proemi del salterio di Origene, Ippolito, Eusebio, Cirillo Alessandrino e altri, con frammenti inediti (Studi e Testi, 142), Città del Vaticano, Biblioteca apostolica vaticana, 1948, pp. 95-104 and M. WALLrafF, The Canon Tables of the Psalms: An Unknown Work of Eusebius of Caesarea, in Dumbarton Oaks Papers 67 (2013) 1-14.

22. Eusebius, De divisione psalteri et psalmorum. Also of this text a critical edition is included in the volume on the prologue material from Origen and Eusebius, for an uncritical edition see PG 23, 66C-68A. 
Origen's as well as Eusebius' compositions are part of the prologue material of psalm catenae, and they are also included in several psalter manuscripts without a catena. From this, we can deduce that the connection of the psalms with the worship in the sanctuary was well known to Origen, Eusebius and their readers. Still, the main purpose of these lists is probably the enumeration of psalm authors.

Modern scholarship has shown that the other information in the headings of the psalms constitutes significant testimony regarding the origins of many of the psalms, particularly because they often provide hints about the practice of performance. However, these hints are barely noticeable as such in the translation of the LXX. Additionally, even though the Christian exegetes put a lot of effort into the explanation of the often rather cryptic lines in the headings and compare the obscure, alternative translations by Aquila, Symmachus and Theodotion, there is hardly a case that a heading was explained in light of the liturgical role of the respective psalm.

\section{The Diapsalma}

$\Delta \mathrm{t} \alpha \psi \alpha \lambda \mu \alpha$ is the standard LXX translation for the Hebrew expression סלה, which occurs in quite a number of psalms at the end of certain verses. The original meaning of this Hebrew terminus is not entirely clear $^{23}$. It always occurs outside sentences and mainly in psalms which were part of the liturgy of the temple. Therefore, it was most likely a sort of stage direction, be it for the chorus, for the musicians, or perhaps for the crowd which took part in the service. The use of its Greek counterpart $\delta$ ió $\psi \alpha \lambda \mu \alpha$ is likewise limited to the LXx, mainly the Book of Psalms, and therefore its meaning is, to some extent, a matter of interpretation ${ }^{24}$. In any case, the word indicates a certain cut in the structure of the text.

From Origen onward, this mysterious term $\delta i \alpha \psi \psi \alpha \lambda \mu \alpha$, it seems, held a special fascination for the Christian interpreters of Psalms. In his extant prologue texts on the psalter, Origen himself deals with the $\delta i \alpha \psi \alpha \alpha \lambda \mu \alpha$ twice. In fact, there are no contradictions between the two passages, although there are some slight differences. In his general introduction to Psalms, he presents his own thoughts on the terminus:

23. For an aged, but nonetheless exhaustive discussion see B. ЈАCOB, Beiträge zu einer Einleitung in die Psalmen. I. Sela, in ZAW 16 (1896) 129-181.

24. For more discussion of this matter F.X. Risch's lecture Das Verständnis von Diapsalma in der antiken Psalmenkommentierung held in 2010, available online via edoc. bbaw.de. 
Since we found in the Septuagint, in Theodotion and in Symmachus in the middle of quite a few psalms the expression $\delta i \alpha ́ \psi \alpha \lambda \mu \alpha$, we asked ourselves if the ones who put it there did not mark with it the change of a certain rhythm or melody or of a part, in accordance with the topics. It is neither written in Aquila nor in the Hebrew, but instead of $\delta \dot{\alpha} \psi \alpha \alpha \lambda \mu \alpha$ there stands "ever" $(\dot{\alpha} \varepsilon \dot{c})^{25}$.

In search for the semantic of $\delta i \alpha \psi \alpha \lambda \mu \alpha$, Origen provides here a set of alternative meanings concerning performance and content of the Psalms. According to him, the terminus may have different functions, which were

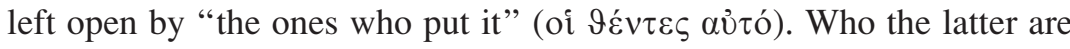
is not said explicitly, but one would assume Origen is speaking here about all Greek translators who use the term, i.e. the translators of the LXX, Theodotion and Symmachus. This is underlined by his last remark about Aquila and "the Hebrew". Apparently, he has complete trust in Aquila's competence, as he states that both have $\dot{\alpha} \varepsilon i^{26}$, so that the actual meaning of סלה is no matter of discussion for him. By setting a $\delta 1 \alpha \psi \alpha \lambda \mu \alpha$ "the ones who put it" seem to act arbitrarily, to a certain degree ignoring the Hebrew text.

Besides this passage from the general introduction, we can consult a shorter treatise on only the $\delta \iota^{\alpha} \psi \alpha \lambda \mu \alpha$ by Origen ${ }^{27}$. Here, he carefully examines the Hebrew and Greek versions of three passages containing the terminus, Ps 74,4;75,4.10. Anticlimactically, the meaning of $\delta i \alpha \psi \alpha \lambda \mu \alpha$ is summed up in a single sentence, which is generally in line the abovequoted passage: "Whether the translators (oi $\varepsilon \rho \mu \eta v \varepsilon v ́ \sigma \alpha \nu \tau \varepsilon \varsigma$ ) wrote the $\delta i \alpha \psi \alpha \lambda \mu \alpha$ on occasion of a change in the musical melody or rhythm, or if they had another motivation, you will discern yourself" 28 .

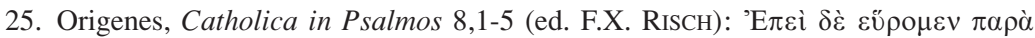

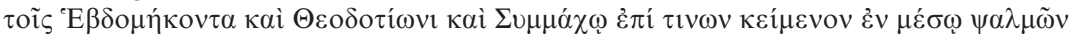

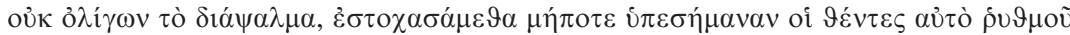

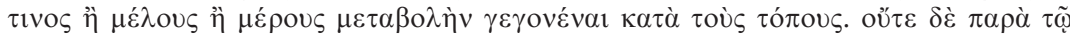

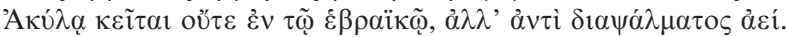

26. It is impossible to check Origen's claim independently, since most of Aquila's translation is lost. Field has ảeí for Aquila in Ps 3,3, the first סלה in the psalter, but this information is based on Origen (see F. FIELD, Origenis Hexaplorum quae supersunt: Sive veterum interpretum Graecorum in totum Vetus Testamentum fragmenta, Oxford, Clarendon, 1875, vol. 2, p. 89).

27. Origenes, De diapsalmate. The text was published by W. RIETZ, De Origenis prologis in psalterium quaestiones selectae, Jena, Pohle, 1914, pp. 11f., a new edition by F.X. Risch is included in the above mentioned volume on the prologue material from Origen and Eusebius (see n. 1).

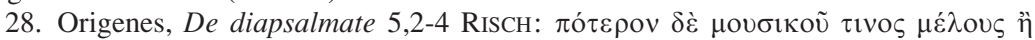

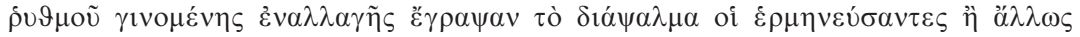

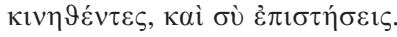


Two points in this statement are remarkable. The first is that Origen formulates it as an open question to his reader rather than as a conclusion. This can be understood as an invitation to further develop his conclusions. Second, here we learn who inserted the $\delta$ ió $\psi \alpha \lambda \mu \alpha$ according to Origen's view, oi $\varepsilon \rho \mu \eta v \varepsilon v ́ \sigma \alpha v \tau \varepsilon \varsigma$. But who might that be? Since Origen spoke before about the different Greek translations of סלה, the meaning "translators (sc. of the LXX)" suggests itself. Thus, writing the $\delta$ í $\psi \alpha \lambda \mu \alpha$ would be part of the process of translating the Hebrew text and therefore only the (inspired) choice for the right equivalent of the Hebrew in Greek ${ }^{29}$. But still, here again arises the possibility for further elaboration.

Eusebius accepts the invitation of his predecessor in a passage of his exceptionally long treatise which was handed down by the catenae under

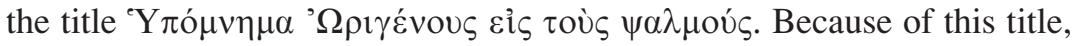
it had long been mistaken as a work of Origen, but Franz Xaver Risch and I discovered that it is a critical discussion of Origen's statements in his general introduction to the Book of Psalms. We demonstrated that the author of this text must be Eusebius ${ }^{30}$. Here Eusebius explains:

According to the copies (sc. of the LXX) which are with us and according to Symmachus the notation $\delta i \alpha ́ \alpha \alpha \lambda \mu \alpha$ seems to stand, when a change in the melody or rhythm occurred. Often also an alteration of meaning happens at the $\delta 1 \alpha \psi \alpha \dot{\alpha} \lambda \mu \alpha \tau$, sometimes also a change of the speaking person ${ }^{31}$.

This last, new facet is fundamental for Eusebius' understanding of the Psalms, since he is almost constantly working with prosopological exegesis. However, the preferred $\pi \rho$ ó $\sigma \omega \pi \alpha$ of Eusebius are, of course, Christ and the Holy Spirit, speaking through the mouth of the prophet David. This leaves little room for speculation about the performance of the Psalms in a liturgical context.

Indeed, handed down under the name Eusebius, but also in some cases anonymous, is another prologue text answering to Origen's above-quoted assessment. Here, the description of the chanting before the Ark from

29. Even though there are indeed sporadic cases, where in the LXX we find a $\delta 1 \alpha \psi \alpha \lambda \mu \alpha$ without a סלה in the Masoretic text, generally both are corresponding. Cf. J. IRIGOIN, Recherches sur le Diapsalma, in Cahiers de Biblia Patristica 4 (1994) 7-20.

30. See the introduction to Eusebius, Hypomnema (ed. BANDT - RISCH) in the already mentioned volume of the prologue material from Origen and Eusebius (n. 1). For a preliminary version of this edition and introduction see C. BANDT - F.X. RISCH, Das Hypomnema des Origenes zu den Psalmen - eine unerkannte Schrift des Eusebius, in Adamantius 19 (2013) 395-436.

31. Eusebius, Hypomnema 14,2-6 (ed. BANDT - RiSCH): $\kappa \alpha \tau \dot{\alpha} \delta \dot{\varepsilon} \tau \grave{\alpha} \pi \alpha \rho$ '

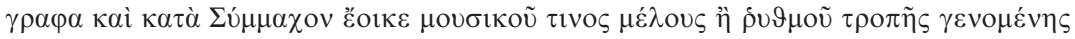

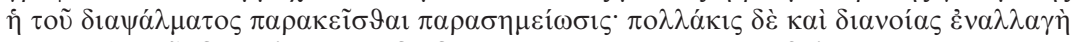

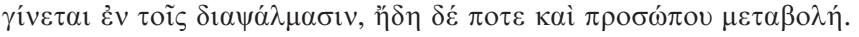


Hippolytus is embedded into Origen's reflections about the $\delta t^{\prime} \psi \alpha \lambda \mu \alpha$.

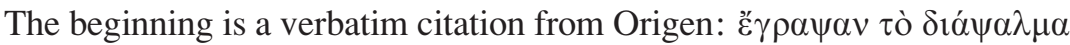
oi $\varepsilon \rho \mu \eta v \varepsilon v ́ \sigma \alpha \nu \tau \varepsilon \varsigma$. But these $\dot{\varepsilon} \rho \mu \eta \varepsilon v ́ \sigma \alpha \nu \tau \varepsilon \varsigma$ are seen as quite different men than in Origen's understanding, which solves the problem that they should have been the ones who originally inserted the $\delta$ ió $\psi \alpha \lambda \mu \alpha$ in the Psalms. 'E $\rho \eta v \varepsilon v ́ \sigma \alpha v \tau \varepsilon \varsigma$ does not hint to the translators of the Septuagint, but to the $\tau \dot{\varepsilon} \sigma \sigma \alpha \rho \varepsilon \varsigma \ddot{\alpha} \rho \chi 0 v \tau \varepsilon \varsigma$, in other words, the four chief musicians who interpreted the Psalms in the sanctuary. The text runs:

The four interpreting chief (musicians) who were chosen by King David from the tribe of Levi wrote down the $\delta$ ió $\psi \alpha \lambda \mu \alpha$, namely Asaf and the sons of Kore, Aiman, Aitham and Idithum. These men follows the number (sc. 288) of singers (or perhaps better: musicians), each of them 72 . They were standing before the sanctuary of the Lord and praised the ruler of the universe, one with cymbals, the other with a harp, the other with a lyre, the other with a horn, the other with a kithara. In their midst stood David and, in this way being the leader of the musicians, he held in his hand the harp. Everyone who was inspired by the Holy Spirit celebrated God in hymns, and all joined in with the Psalm performer singing Hallelujah. But whenever the grace of the Holy Spirit withdrew for a short moment and the instruments were not inspired, it seems likely that also in these cases they wrote down the $\delta 1 \alpha \dot{\alpha} \alpha \lambda \mu \alpha^{32}$.

Admittedly, some practical problems are neglected in this fascinating description. How could the musicians chant and write at the same time? Shall we then deduce that there were tachygraphers present in the temple to document the inspired music? And if so, was it these tachygraphers who wrote down the $\delta 1 \alpha \psi \alpha \dot{\lambda} \mu \alpha \tau \alpha$ ? Nevertheless, here we finally find unambiguous proof that a patristic author was aware and approved of the relationship between the Psalms and the worship in the sanctuary, since, obviously, at least the psalms containing a $\delta i \alpha ́ \psi \alpha \lambda \mu \alpha$ were composed during such a celebrated event.

Eusebius' authorship of this text, however, is doubtful. Not only because this description does not concur with the above-quoted passage on the

32. Eusebius(?), De diapsalmate 1-10 (corresponds to PG 23, 76BC, critical edition

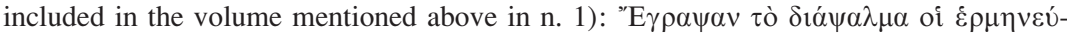

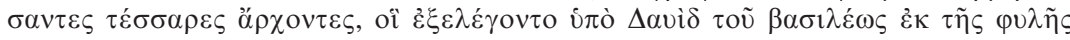

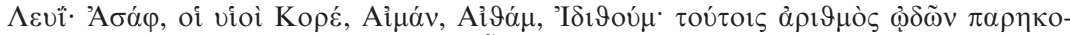

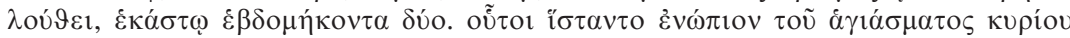

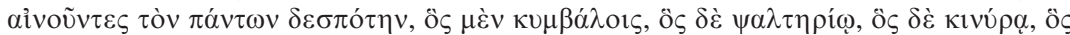

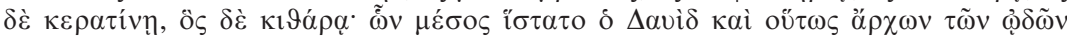

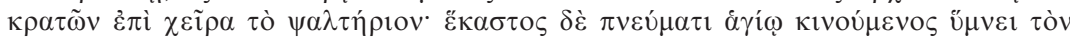

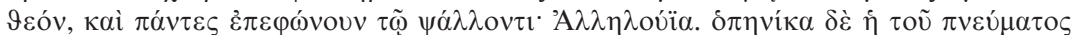

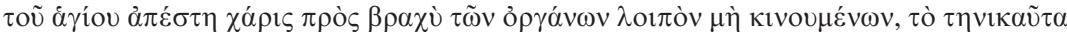

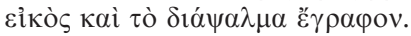


$\delta i \alpha \psi \alpha \lambda \mu \alpha$ from the Hypomnema, but also because he generally uncouples the Psalms from the worship in the sanctuary. His main concern is rather the content of each psalm and its message to the Christian church. Still, the text must have been composed in the time of Eusebius or shortly thereafter, since it was known to Diodor of Tarsus.

Diodor speaks in his Commentary on Psalm 5 about the meaning and function of the $\delta i \alpha \psi \alpha \lambda \mu \alpha$ and, for him, the topic has almost dogmatic value. He enumerates the explanations of his predecessors without naming them. Moreover, he sharply rejects any other explanation than the musical one, especially the idea of a pneuma that comes and goes away from a

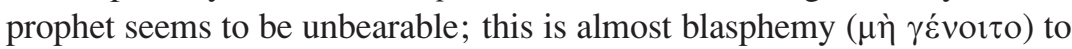
him. Similarly, the possibility that a change of meaning might take place within a psalm is refuted again and again ${ }^{33}$.

\section{Conclusion}

Unquestionable, psalms played an important role in early Christian religious life. In fact, the Book of Psalms is the part of the Septuagint which was most widely read and studied and which most obviously formed an element of Christian identity. Therefore, in general, Christian exegetes' interest in the historical Jewish worship and its connection to the psalms is not particularly pronounced; partially $\psi \alpha \lambda \mu \omega \delta i \alpha$ and sacrifice were even set in contrast. Nonetheless, the detailed biblical reports about all the effort David put into the worship before the sanctuary as well as certain features of the psalms themselves, especially the mysterious term $\delta i \alpha ́ \psi \alpha \lambda \mu \alpha$, captured the imagination of some patristic authors. From their

33. Cf. Diodor, In Psalmos, Ps 5,3 (CCSG 6, 8-32 OLIVIER): $\Delta$ ió $\psi \alpha \lambda \mu \alpha \mu \grave{\varepsilon} \nu$ oũv

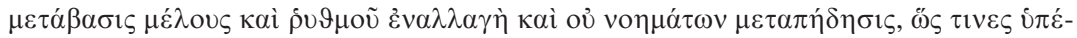

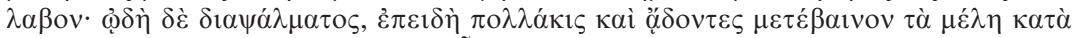

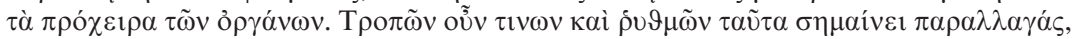

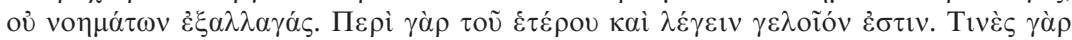

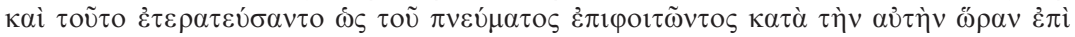

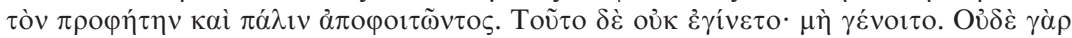

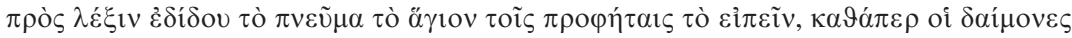

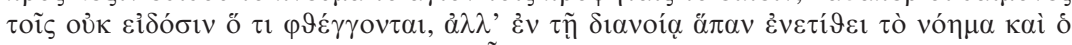

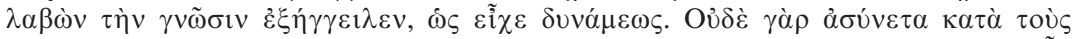

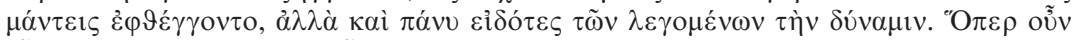

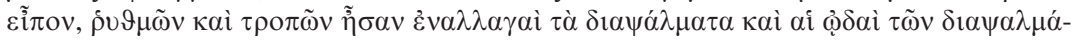

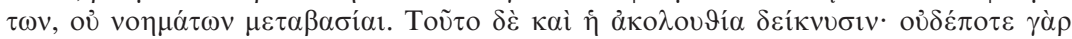

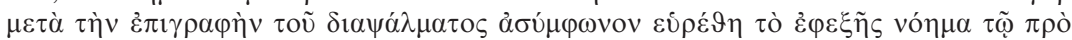

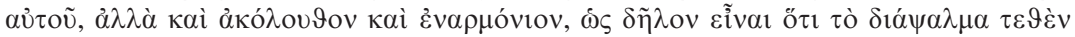

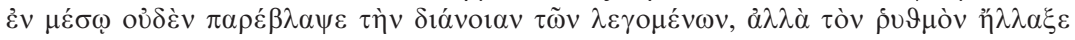

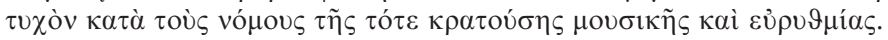


speculations eventually arose the impressing picture of David surrounded by large bands of musicians altogether inspired by the Holy Spirit performing and thereby composing the psalms. Even though this vision was not accepted by some other Christian exegetes, it certainly did add another facet to the fascination of the Holy City of Jerusalem.

Berlin-Brandenburgische Akademie

Cordula BANDT

der Wissenschaften

Vorhaben ,Die alexandrinische und

antiochenische Bibelexegese in der Spätantike“

Jägerstr. 22/23

DE-10117 Berlin

Germany

bandt@bbaw.de 